\title{
ANALISIS PENGARUH MARKETING MIX TERHADAP PENGAMBILAN KEPUTUSAN NASABAH MENABUNG PADA BANK JATENG CABANG UNGARAN
}

\author{
Dyah Ayu Annurfa *) \\ Aris Sunindyo **) \\ *) dyahayuannurfa97@gmail.com
}

\begin{abstract}
This research is aimed to analyze and identify the signification influence of product ,price, promotion and place to the saving deccison at Bank Jateng Cabang Ungaran and partially. Data were collected through questionnaires to 100 respondents who are customers of saving at Bank Jateng Cabang Ungaran. Which is obtained by using purposive sampling technique. The calssical assumption of normality test,multicoloniarity, heteroscedasticity test and multiople linier analysis test and coefficient of determination. The hypothesis proved using the $t$ and $F$ test. The results of this study indicate that the product, price, promotion, placesimultaneously have significanctly influence against the customer's decision to save. Partially there are one significant variabels that influence the customer decision saving of promotion. For product, price, place variables not significant on the customer's decision to save at Bank Jateng Cabang Ungaran
\end{abstract}

Keywords : Marketing mix contains product, price, promotion, place and saving Decision.

*) Mahasiswa Tugas Akhir Prodi Keuangan dan Perbankan, Jurusan Akuntansi, Politeknik Negeri Semarang

**) Dosen Jurusan Akuntansi Politeknik Negeri Semarang

\section{PENDAHULUAN}

\section{Latar Belakang}

Menurut Undang-Undang Nomor 10 Tahun 1998, bank adalah badan usaha yang menghimpun dana dari masyarakat dalam bentuk simpanan dan menyalurkannya ke masyarakat dalam bentuk kredit dan atau bentuk-bentuk lainnya dalam rangka meningkatkan taraf hidup rakyat banyak. Hampir semua sektor yang berhubungan dengan kegiatan keuangan selalu membutuhkan jasa bank. Dapat dilihat bahwa ketika perekonomian Indonesia mengalami penurunan atau melemah, sektor perbankan terkena imbas dari melemahnya ekonomi Indonesia. Begitu pentingnya dunia perbankan, sehingga ada anggapan bahwa bank merupakan "nyawa" untuk menggerakkan roda perekonomian suatu negara. Dengan pentingnya peranan perbankan dalam meningkatkan pertumbuhan di sektor ekonomi, maka salah satu upaya yang dapat dilakukan ialah peningkatan kinerja bank guna dapat mempertahankan kelangsungan hidup, melalui penerapan pemasaran produk bank. Dimana dengan penerapan pemasaran produk bank yang memadai, maka akan dapat dipengaruhi terhadap peningkatan pendapatan jasa perbankan. 
Salah satu faktor yang menjadi penunjang dalam pemasaran produk adalah yang berkaitan dengan keputusan nasabah dalam memilih produk bank. Keputusan merupakan salah satu elemen penting dari perilaku nasabah disamping kegiatan fisik yang melibatkan nasabah dalam menilai , mendapatkan, dan mempergunakan barang - barang serta jasa ekonomis. Nasabah selalu ingin mendapatkan produk dan jasa serta pemuas kebutuhan yang dapat memenuhi kebutuhan hidup mereka. Pengambilan keputusan merupakan suatu kegiatan individu yang secara langsung terlibat dalam mendapatkan dan mempergunakan barang yang ditawarkan. Nasabah memiliki kedudukan sebagai salah satu kekuatan kompetitif melalui daya tawarnya. Daya tawar nasabah menjadi sangat penting, karena merekalah yang memiliki kebutuhan dan keinginan. Untuk memenuhi kebutuhan dan keinginan hidup, mereka jugalah yang mempunyai sarana pembelian (waktu dan uang), dalam menentukan pilihan dan mengambil keputusan.

Faktor bauran pemasaran memiliki peran besar dalam berbagai bidang usaha bisnis, bisnis perbankan yang menjadi salah satu sektor usaha tentu jelas memiliki bauran pemasaran disebabkan karena perbankan memiliki produk yang dipasarkan dan nasabah sebagai penabung di bank, dikeluarkannya produk dengan harga yang sesuai dengan nilai produk tersebut. Bunga yang kompetitif hingga ke promosi yang dapat mengirimkan informasi jelas menarik bagi masyarakat merupakan bagian dari bauran pemasaran. Oleh karena itu, pihak perbankan harus memberikan berbagai motivasi dan kepercayaan sehingga masyarakat berminat untuk menanamkan dananya.

Untuk dapat mempertahankan keberadaannya, maka bank harus melakukan kegiatan bauran pemasaran dalam usaha menarik dana dari masyarakat. Bauran pemasaran tersebut tersebuty yaitu dengan memberikan berbagai kemudahan pengurusan, tingkat bunga yang kompetitif, adanya inovasi produk, pembukaan cabang - cabang di daerah sehingga mudah terjangkau serta promosi berbagai hadiah undian bagi setiap nasabah. Menurut Undang Undang Perbankan No.10 Tahun 1998. Pasal 1 ayat 1, "Perbankan merupakan segala sesuatu yang menyangkut tentang bank, mencakup kelembagaan, kegiatan usaha, serta cara dan proses dalam melaksanakan kegiatan usahanya". Sedangkan bank adalah badan usaha yang menghimpun dana masyarakat dalam bentuk simpanan dan menyalurkannya kepada masyarakat dalam bentuk kredit dan/atau bentuk - bentuk lainnya dalam rangka meningkatkan taraf hidup rakyat banyak (Undang - Undang Perbankan No. 10 Tahun 1998, Pasal 1 ayat 2). Sehingga dapat disimpulkan bahwa bank merupakan perusahaan yang bergerak dalam keuangan. Aktivitas perbankan yang pertama disebut dengan istilah funding yaitu menghimpun dana dalam bentuk simpanan dari masyarakat, maka oleh perbankan dana tersebut diputar 
kembali atau dijual kembali ke masyarakat dalam bentuk pinjaman atau lebih dikenal dengan kredit lending.

Bank Jateng Cabang Ungaran adalah salah satu bank pemerintah daerah juga menghadapi tantangan yang sama dengan bank - bank umum lainnya. Persaingan antar bank berimbas pada sulitnya menarik nasabah sebagai pelanggan tetap di Bank Jateng Cabang Ungaran. Pada era globalisasi pada saat ini persaingan bank sanagat ketat sekali, karena bank BUMN, bank swasta, dan bank asing yang telah membuka cabang- cabang di seluruh pelosok Indonesia.

Bank Jateng dalam kegiatan oprasionalnya menghimpun dana masyarakat secara langsung, salah satunya melalui tabungan. Adapun produk - produk tabungan yang ditawarkan kepada masyarakat yaitu sebagai berikut pada Tabel 1 .

Tabel 1 Informasi Produk Tabungan

\begin{tabular}{|l|l|r|r|l|}
\hline No. & \multicolumn{1}{|c|}{ Nama Produk } & $\begin{array}{c}\text { Setoran } \\
\text { Awal } \\
\text { Minimum }\end{array}$ & $\begin{array}{c}\text { Setoran } \\
\text { Selanjutnya } \\
\text { Minimum }\end{array}$ & \multicolumn{1}{|c|}{ Bunga } \\
\hline 1 & Tabungan Bima & Rp10.000 & Rp5.000 & $\begin{array}{l}\text { Dihitung secara progresif } \\
\text { harian }\end{array}$ \\
\hline 2 & Tabungan Simpeda & Rp10.000 & Rp5.000 & $\begin{array}{l}\text { Dihitung secara progresif } \\
\text { harian }\end{array}$ \\
\hline 3 & TabunganKu & Rp20.000 & Rp10.000 & $\begin{array}{l}\text { Dihitung berdasar saldo } \\
\text { harian dan tidak progresif }\end{array}$ \\
\hline 4 & Tabungan SimPel & Rp5.000 & Rp1.000 & Tidak mendapat bunga \\
\hline
\end{tabular}

Sumber : www.bankjateng.co.id

Berdasarkan Tabel 1 dapat dilihat bahwa produk - produk tabungan Bank Jateng yang ditawarkan kepada masyarakat cukup beragam sesuai dengan kebutuhan masyarakat. Sehingga dapat menarik minat masyarakat untuk menyimpan dananya pada Bank Jateng. Produk dan jasa harus di kelola dengan baik agar melekat pada benak masyarakat. Masyarakat akan tertarik dengan kualitas pelayanan yang baik dan Beberapa sumber jurnal yang membantu dalam meningkatkan menaruh kepercyaan terhadap nama dari perusahaan itu sendiri. Pada bank Jateng Cabang Ungaran memiliki jumlah nasabah sebanyak 40.941 nasabah.

Perbaikan dan inovasi-inovasi baru terus dilakukan, sehingga kinerja Bank Jateng semakin tumbuh dan berkembang. Pada tahun 2018, total aset telah mencapai Rp 65.628.948 (dalam juta rupiah) atau tumbuh 6,7\% dari tahun 2017 sebesar Rp61.466.427 (dalam juta rupiah) dan Dana Pihak Ketiga (DPK) yang dihimpun mencapai Rp 61.466.427 (dalam juta rupiah) atau tumbuh 19,4\% dari tahun 2017 sebesar Rp 50.124.555 (dalam juta rupiah). Serta kredit yang diberikan juga mengalami peningkatan mencapai Rp 43.101 .421 (dalam juta 
rupiah) atau tumbuh 7,06\% dari tahun 2017 sebesar $\mathrm{Rp} 40.257 .787$ (dalam juta rupiah) (www.ojk.go.id).

Berdasarkan Dana Pihak Ketiga (DPK) Bank Jateng, maka dapat dilihat bahwa DPK Bank Jateng mengalami penurunan di tahun 2018, sehingga Bank Jateng harus berupaya untuk meningkatkan jumlah DPKnya dengan melakukan pendekatan melalui strategi bauran pemasaran atau marketing mix yang dapat mempengaruhi keputusan nasabah untuk menabung. Karena peran marketing mix turut menentukan keberhasilan produk yang dikeluarkan perusahaan.

Sehingga dari penelitian tersebut dihasilkan research gap pada penelitian ini bagaimana marketing mix mempengaruhi keputusan nasabah menabung beberapa penelitian yang telah dilakukan ini menghasilkan hasil yang berbeda-beda. Berdasarkan atas penelitian Mayangsari (2013), Sukotjo dan Radix (2010), Agus dan Ikhwan (2014), dan Wilopo dkk (2013) menunjukkan bahwa variabel produk (product) berpengaruh signifikan sedangkan dalam penelitian Kurnianto (2013) variabel produk (product) berpengaruh secara signifikan terhadap pengambilan keputusan nasabah menabung. Sedangkan dilihat dari sisi harga (price) dalam penelitian, Ikhwan (2014), dan Kurnianto (2013) variabel harga (price) berpengaruh yang signifikan. Kemudian pada variabel tempat (place) yang memiliki pengaruh signifikan adalah penelitian yang dilakukan Mayangsari (2013), Sukotjo dan Radix (2010), Agus Ikhwan (2014), dan Wilopo dkk (2013) dan dalam penelitian Kurnianto (2013) tidak memiliki pengaruh signifikan.

Berdasarkan uraian latar belakang diatas maka, dapat diketahui bahwa Bank Jateng belum mampu menjadi Bank Pembangunan Daerah yang terbaik. Hal tersebut menunjukkan bahwa persaingan dunia perbankan di Indonesia semakin kompetitif. Oleh sebab itu Bank Jateng harus mampu mengkombinasi marketing mix agar nasabah dan calon nasabah menyimpan uangnya pada Bank Jateng dan tidak beralih ke bank lain. Dari masalah diatas memunculkan masalah penelitian sebagai berikut:

Bagaimana pengaruh produk (product) secara parsial terhadap pengambilan keputusan nasabah menabung pada Bank Jateng Kantor Cabang Ungaran. Bagaimana pengaruh harga (price) secara parsial terhadap pengambilan keputusan nasabah menabung pada Bank Jateng Kantor Cabang Ungaran. Bagaimana pengaruh lokasi (place) secara parsial terhadap pengambilan keputusan nasabah menabung pada Bank Jateng Kantor Cabang Ungaran. Bagaimana pengaruh promosi (promotion) secara parsial terhadap pengambilan keputusan nasabah menabung pada Bank Jateng Kantor Cabang Ungaran . Bagaimana pengaruh produk 
(product), harga (price), tempat (place), promosi (promotion), secara simultan terhadap pengambilan keputusan nasabah menabung pada Bank Jateng Kantor Cabang Ungaran?

\section{KAJIAN TEORI}

\section{Pengertian dan Fungsi Bank}

Menurut Undang-Undang No.10 Tahun 1998 tentang perbankan, dikemukakan bahwa pengertian bank adalah sebagai badan usaha yang menghimpun dana dari masyarakat dalam bentuk simpanan dan menyalurkannya kepada masyarakat dalam bentuk kredit dan atau bentuk-bentuk lainnya dalam rangka meningkatkan taraf hidup rakyat banyak. Sedangkan menurut Kasmir (2011:25) bahwa, bank merupakan perusahaan yang bergerak dibidang keuangan. Artinya aktivitas perbankan selalu berkaitan dalam bidang keuangan artinya aktivitas perbankan selalu berkaitan dalam bidang keuangan, yang kegiatannya adalah menghimpun dana dari masyarakat (funding) dan menyalurkan kembali dana tersebut ke masyarakat dalam bentuk kredit (lending) serta memberikan jasa- jasa bank lainnya. Sedangkan menurut Undang - Undang Republik Indonesia No. 19 Tahun 1998 tentang perbankan dalam pasal 1 ayat 2 bank adalah badan usaha yang menghimpun dana dari masyarakat dalam bentuk kredit atau dalam bentuk - bentuk lainnya dalam rangka meningkatkan taraf hidup rakyat banyak.

\section{Pengertian Tabungan}

Secara umum tabungan merupakan salah satu kegiatan perbankan yang diberikan kepada masyarakat yang membutuhkan jasa penyimpan uang. Menurut Undang - Undang No.10 tahun 1998 pasal 1 ayat 9, tabungan merupakan simpanan yang penarikannya hanya dapat dilakukan menurut syarat - syarat tertentu yang disepakati hanya dapat dilakukan menurut syarat- syarat tertentu yang disepakati, tetapi tidak dapat ditarik dengan cek, bilyet giro, atau lainnya yang dipersamakan dengan itu. Sedangkan menurut Taswan (2010:58) tabungan adalah simpanan yang pada bank yang penarikannya sesuai dengan persyaratan yang ditetapkan oleh bank.

\section{Pengertian Pemasaran Bank}

Pemasaran merupakan kegiatan yang sangat diperlukan oleh bank agar dapat bersaing dengan para pesaing, yakni dengan menawarkan produk yang menarik bagi nasabah, oleh karena itu, pemasaran merupakan kegiatan yang dijalankan dalam suatu bank. Tanpa adanya pemasaran maka kebutuhan dan keinginan nasabah tidak dapat terpenuhi. Menurut Kasmir (2012:171) tujuan pemasaran bank: Memaksimumkan konsumsi atau dengan kata lain memudahkan dan menarik minat konsumsi, sehingga dapat menarik nasabah untuk membeli produk yang ditawarkan bank secara berulang - ulang. Memaksimumkan kepuasan konsumen 
melalui berbagai pelayanan yang diinginkan nasabah. Memaksimumkan pilihan (ragam produk) dalam arti bank menyediakan berbagai jenis produk bank sehingga nasabah memiliki beragam pilihan pula. Memaksimumkan mutu hidup dengan memberikan kemudahan kepada nasabah dan menciptakan iklim yang efisien. Manajemen pemasaran adalah suatu analisis, perencanaan, pelaksanaan serta kontrol program - program yang telah direncanakan dalam hubungan dengan pertukaran - pertukaran yang diinginkan terhadap konsumen yang dituju untuk memperoleh keuntungan pribadi bersama (Lupiyoadi, 2006:6)

\section{Marketing Mix (Bauran Pemasaran)}

Merupakan kegiatan pemasaran yang dilakukan secara terpadu. Artinya kegiatan ini dilakukan secara bersamaan diantara elemen - elemen yang ada dalam marketing mix itu sendiri. Setiap elemen tidak dapat berjalan sendiri - sendiri tanpa dukungan dari elemen yang lain. Penggunaan bauran pemasaran (marketing mix) dalam dunia perbankan dilakukan dengan menggunakan konsep - konsep yang sesuai dengan kebutuhan bank. Dalam praktiknya, konsep bauran pemasaran terdiri dari bauran pemasaran untuk produk yang berbentuk barang jasa diperlakukan konsep yang sedikit berbeda dengan produk barang. Kotler menyebutkan 4 konsep bauran pemasaran (marketing mix) terdiri dari Produk, Harga, Promosi dan Tempat (Kasmir, 2014:213).

\section{Product (Produk)}

Produk merupakan keseluruhan konsep objek suatu yang memberikan sejumlah nilai kepada konsumen (Lupiyoadi) dan Hamdanbi (2006:70). Dalam penelitian ini indikator yang digunakan pada variabel produk (product) menurut (Lupiyoadi \& Hamdani, 2006:81) adalah Produk yang beragam, Produk yang mampu bersaing dengan bank lain, Produk yang sesuai dengan keinginan dan kebutuhan.

\section{Physical Evidence (Bukti Fisik)}

Physical Evidence merupakan lingkungan dimana jasa disampaikan serta pelanggan berinteraksi, dan kompenen-kompenen yang berwujud apapun yang menunjukkan kinerja dari fasilitas atau komunikasi dari jasa. Bukti fisik dari setiap bisnis berlainan (Yevis Marty Oesman,2010).

\section{Pengambilan Keputusan}

Menurut Kotler dan Keller (2009:235) proses keputusan pembelian terdiri dari lima tahap, yaitu pengenalan masalah, pencarian informasi, evaluasi alternatif, keputusan pembelian dan perilaku pasca pembelian. 


\section{Kerangka Pemikiran}

Menurut Wiyono (2011 : 36) Kerangka pikir yang baik dapat menjelaskan secara teoritis antara hubungan antar variabel yang diteliti. Hubungan variabel tersebut selanjutnya dirumuskan kedalam paradigma penelitian. Kerangka pemikiran teoritis yang digunakan dalam penelitian ini secara sistematis dan sederhana dapat terlihat pada gambar dibawah:

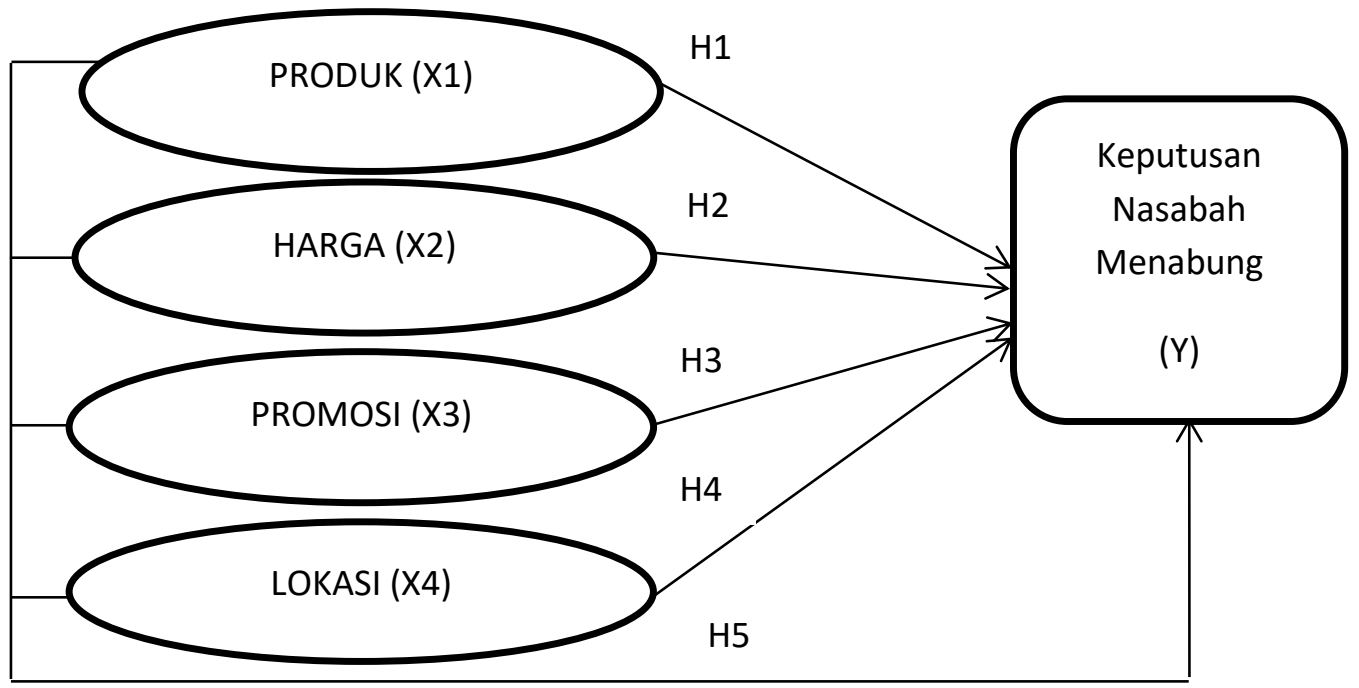

\section{Gambar 1 Model Kerangka Pemikiran}

Sumber : Data diolah tahun 2019

\section{METODE PENELITIAN}

Menurut Ali dalam dan Achamadi (2003:2) menyatakan bahwa metodologi penelitian merupakan ilmu yang mempelajari cara-cara melakukan pengamatan dengan pemikiran secara tepat secara terpadu melalui tahapan-tahapan yang disusun secara ilmiah untuk mencari, menyusun serta menganalisis dan menyimpulkan data-data, sehingga dapat dipergunakan untuk menemukan, mengembangkan dan menguji kebenaran sesuatu pengetahuan berdasarkan bimbingan Tuhan.

\section{Pengukuran Variabel (Parameter Variabel)}

Skala Likert adalah skala yang digunakan untuk persepsi, sikap atau pendapat seseorang atau kelompok mengenai sebuah peristiwa atau fenomena sosial, berdasarkan definisi operasional variabel yang telah ditetapkan oleh peneliti. Variabel yang akan diukur untuk menyusun item - item instrumen dengan menghadapkan responden pada pertanyaan, kemudian memberi jawaban atas pertanyaan yang diberikan. Menurut Sugiyono (2017:93), skala likert yaitu skala yang digunakan untuk mengukur sikap, persepsi seseorang atau sekelompok orang tentang fenomena sosial, dengan pembagian sebagai berikut:

Sangat Tidak Setuju : diberi skor 1 
Tidak Setuju : diberi skor 2

Setuju : diberi skor 3

Sangat Setuju : diberi skor 4

$$
\mathrm{n}=\frac{N}{1+N(e)^{2}}
$$

Keterangan :

$\mathrm{n}=$ Ukuran sampel

$\mathrm{N}=$ Ukuran populasi

$\mathrm{e}=$ Tingkat kesalahan yang ditoleransi $10 \%$

Dalam perhitungan sampel ini ukuran populasi yang digunakan berdasarkan jumlah nasabah tabungan Bank Jateng Cabang Ungaran yaitu sebanyak 40. 941 Perhitungan sampel dalam penelitian ini adalah sebagai berikut :

$n=\frac{40.941}{1+40.941(0,10)^{2}}$

$n=\frac{40.941}{410,41}$

$n=99,75634$ atau dibulatkan menjadi 100

\section{Metode Pengumpulan Data}

Metode pengumpulan data yang digunakan dalam penelitian ini adalah wawancara, kuesioner, dan studi pustaka sebagai berikut :

\section{Wawancara}

Wawancara adalah proses tanya jawab dalam penelitian dalam penelitian yang berlangsung secara lisan dalam mana dua orang atau lebih bertatap muka mendengarkan secara langsung informasi informasi atau keterangan keterangan (Narbuko dan Achmadi, 2008:83).

\section{Kuesioner}

Metode kuesioner adalah suatu daftar yang berisikan rangkaian pertanyaan mengenai sesuatu masalah atau bidang yang akan diteliti. Untuk memperoleh data, kuesioner disebarkan kepada responden (orang-orang yang menjawab jadi yang diselidiki, terutama pada penelitian survei (Narbuko dan Achmadi, 2008:76).

\section{Studi Pustaka}

Studi pustaka yaitu teknik pengumpulan data melalui majalah, buku - buku, literatur literatur, dan berbagai artikel yang berkaitan dengan penelitian ini. 


\section{Analisis Data}

\section{Uji Validitas}

Uji Validitas digunakan untuk mengukur sah atau tidaknya suatu kuesioner. Suatu kuesioner. Suatu kuesioner dikatakan valid jika pertanyaan pada kuesioner mampu untuk mengungkapkan sesuatu yang akan diukur oleh kuesioner tersebut. Misalkan kita ingin mengukur AUTONOMI seorang karyawan dan karyawan tersebut diberi 4 pertanyaan, maka pertanyaan tersebut harus dapat secara tepat mengungkapkan tingkat AUTONOMI. Jadi validitas ingin mengukur apakah pertanyaan dalam kuesioner yang sudah kita buat betul betul dapat mengukur apa yang hendak kita ukur. (Ghozali, 2016:52).

\section{Analisis Regresi Linear Berganda}

Untuk menganalisis pengaruh atau hubungan variabel bebas (X) yaitu produk, harga, promosi, tempat (Y) yaitu, keputusan nasabah menabung pada Bank.

\section{HASIL DAN PEMBAHSAN}

\section{Uji Normalitas}

Hasil uji normalitas dapat dilihat pada Gambar 2.

Histogram

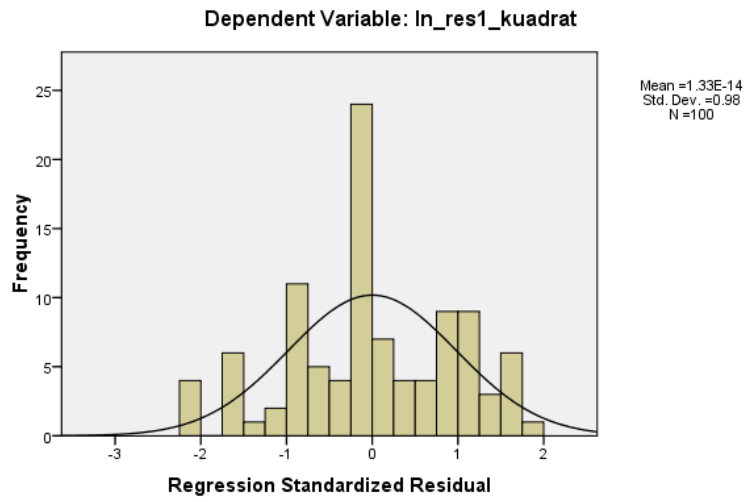

\section{Gambar 2 Hasil Uji Normalitas Histogram}

Sumber : Data Primer yang diolah 2019

Pada Gambar 2 dapat dilihat bahwa grafik histogram mengikuti arah garis diagonal atau tidak menceng ke kiri atau ke kanan atau dapat dikatakan garis histogram pola distribusi normal. Analisis yang kedua yaitu dengan melihat grafik normal probability plot. Hasil uji normalitas berupa analisis grafik normal probability plot dapat dilihat pada Gambar 3 . 


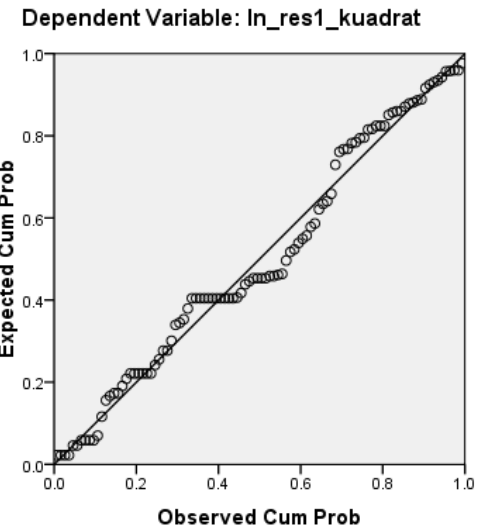

\section{Gambar 3 Hasil Uji Normalitas Probability Plot}

Sumber : Data Primer yang diolah 2019

Dari Gambar 3 dapat dilihat grafik normal probability plot menunjukkan titik-titik menyebar disekitar garis diagonal dan mengikuti arah garis diagonalnya, hal ini dapat dikatakan bahwa model regresi memenuhi asumsi normalitas.

Analisis yang ketiga dengan menggunakan Kolmogorov Smirnov yang dapat dilihat pada Tabel 2.

\section{Tabel 2 Hasil Uji Kolmogorov Smirnov}

One-Sample Kolmogorov-Smirnov Test

\begin{tabular}{|ll|l|}
\hline & & keputusan_menabung \\
\hline N & & 100 \\
Normal Parameters & Mean & 12,21884 \\
& Std. Deviation & 2,767324 \\
Most Extreme Differences & Absolute &, 179 \\
& Positive &, 179 \\
Kolmogorov-Smirnov Z & Negative &,- 115 \\
Asymp. Sig. (2-tailed) & & 1,788 \\
\hline
\end{tabular}

a. Test distribution is Normal.

b. Calculated from data.

Sumber : Data Primer yang diolah 2019

\section{Uji Heteroskedatisitas}

Uji Heteroskedastisitas bertujuan untuk menguji apakah dalam model regresi terjadi variance dari residual suatu pengamatan ke pengamatan lain tetap, maka disebut homoskedastisitas dan jika berbeda disebut heteroskedastisitas. Heteroskedastisitas dapat dideteksi dengan menggunakan Scatterplot sebagaimana dapat dilihat pada gambar 4. 
Scatterplot

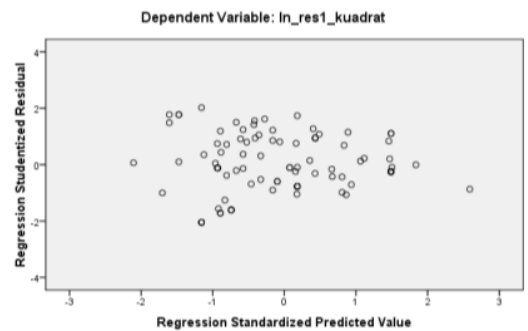

\section{Gambar 4 Hasil Uji Heteroskedastisitas}

Sumber : Data Primer yang diolah 2019

Berdasarkan Gambar 4 pada grafik Scatter Plot menunjukkan bahwa titik - titik menyebar secara acak serta tersebar baik diatas maupun dibawah angka 0 (nol) pada sumbu Y. Hal ini dapat disimpulkan bahwa tidak terjadi heterskedastisitas pada model regresi, sehingga model regreasi tersebut layak untuk digunakan memprediksi Keputusan Menabung pada Bank Jateng Cabang Ungaran.

Untuk dapat memastikan dengan jelas bahwa tidak terdapat heteroskedastisitas dalam penelitian ini dan agar lebih menjamin keakuratan hasil data,maka diperlukan adanya uji Glejser. Berikut merupakan hasil dari Uji Glejser dapat dilihat pada Tabel 3.

Tabel 3 Hasil Uji Glejser

\begin{tabular}{|c|c|c|c|c|c|c|}
\hline & & \multicolumn{5}{|c|}{ Coefficients" } \\
\hline \multirow{2}{*}{\multicolumn{2}{|c|}{ Model }} & \multicolumn{2}{|c|}{ Unstandardized Coefficients } & \multirow{2}{*}{$\begin{array}{c}\text { Standardized } \\
\text { Coefficients }\end{array}$} & \multirow[b]{2}{*}{$\mathrm{t}$} & \multirow[b]{2}{*}{ Sig. } \\
\hline & & B & Std. Error & & & \\
\hline \multirow[t]{5}{*}{1} & (Constant) & .154 & .125 & & 1.232 & .221 \\
\hline & In_zx3_kuadrat & .025 & .042 & .071 & .589 & .557 \\
\hline & In_zx1_kuadrat & .095 & .081 & 203 & 1.563 & .121 \\
\hline & In_zX2_kuadrat & -.005 & .048 & -.014 & -.103 & .918 \\
\hline & In_zx4_kuadrat & -.005 & .049 & -.015 & -.109 & .913 \\
\hline
\end{tabular}

a. Dependent Variable : Keputusan Menabung

Sumber : Data Primer yang diolah 2019

Berdasarkan hasil Uji Glejser pada Tabel 3 menunjukkan bahwa tidak ada satupun variabel independen yang signifikan secara statistik mempengaruhi variabel dependen. Hal ini dapat dilihat signifikannya diatas 0,05 yang berarti terdapat heteroskedastisitas maka, agar tidak terjadi heteroskedastisitas menggunakan uji transformasi kuadrat agar tidak terjadi heteroskedastisitas. 


\section{KESIMPULAN DAN SARAN}

\section{Kesimpulan}

Berdasarkan penelitian ini dengan judul Analisis Marketing Mix Terhadap Pengambilan Keputusan Nasabah Menabung Pada Bank Jateng Cabang Ungaran dapat ditarik kesimpulan :

1. Variabel Produk (product) secara parsial berpengaruh tidak signifikan terhadap keputusan nasabah menabung pada Bank Jateng Cabang Ungaran.

2. Variabel Harga (price) secara parsial berpengaruh tidak signifikan terhadap pengambilan keputusan nasabah menabung pada Bank Jateng Cabang Ungaran.

3. Variabel Promosi (promotion) secara parsial berpengaruh signifikan terhadap pengambilan keputusan nasabah menabung pada Bank Jateng Cabang Ungaran.

4. Variabel Tempat (place) secara parsial berpengaruh tidak signifikan terhadap pengambilan keputusan nasabah menabung pada Bank Jateng Cabang Ungaran.

5. Dimensi marketing mix meliputi Produk (product), Harga(price), Promosi(promotion), Tempat(place) secara simultan berpengaruh signifikan terhadap pengambilan keputusan nasabah menabung pada Bank Jateng Cabang Ungaran.

\section{Saran}

Adapun saran yang dapat diberikan dari hasil penelitian ini, adalah sebagai berikut

1. Disarankan kepada peneliti selanjutnya untuk dapat meneliti dengan membandingkan penggunaan strategi marketing mix terhadap dua objek yang nanti hasilnya akan dibandingkan satu sama lain.

2. Disarankan kepada peneliti selanjutnya untuk lebih menambah indikator dalam variabel penelitian mendatang agar lebih akurat pada hasil yang diperoleh dalam penelitian dilakukan.

Disarankan untuk peneliti tersebut untuk menambah jumlah responden yang diteliti dalam penelitian tersebut untuk keakuratan hasil yang diperoleh dari penelitian yang dilakukan.

\section{DAFTAR PUSTAKA}

Agus dan Ikhwan. 2014 Analisis Pengaruh Bauran Pemasaran Jasa Terhadap Keputusan Memilih Program Studi (Studi Pada Jurusan Akuntansi Dan Jurusan Administrasi Bisnis Di Politeknik Negeri Banjarmasin). Vol 2.No.2

Ayu, Mayangsari. 2013. Pengaruh Marketing Terhadapa Keputusan Konsumen Untuk Menabung Pada Bank Perkreditan Rakyat (BPR Dana Raya Manado)

Bank Indonesia. Undang - Undang Republik Indonesia No.10 Tahun 1998. Tentang Perbankan. 
Wilopo, dkk.2013.Pengaruh Bauran Pemasaran Terhadap Keputusan Menabung Pada Nasabah Bank Muamalat Cabang Malang. Jurnal Administrasi Bisnis (JAB) /Vol.6 No.2 Desember 2013

Ghozali, Imam.2006. Aplikasi Analisis Multivariate Dengan Program SPSS, Edisis Ketiga. Semarang: badan Penerbit Universitas Diponegoro Semarang.

Ghozali, Imam.2011. Aplikasi Analisis Multivariate Dengan Program SPSS, Edisis Kelima. Semarang: badan Penerbit Universitas Diponegoro Semarang.

Ghozali, Imam.2016. Aplikasi Analisis Multivariate Dengan Program SPSS, Edisis Kedelapan. Semarang: badan Penerbit Universitas Diponegoro Semarang.

Irfandi J,Muhammda.2013. Analisis Pengaruh Bauran Pemasaran Terhadap Keputusan Nasabah Dalam Memilih Tabungan Siaga Bukopin pada PT.Bank Bukopin Tbk Di Makassar. Skripsi. Makassar :Universitas Hasanudin.

Kasmir,2004.Pemasaran Bank. Jakarta: Kencana.

Kasmir, 2012. Manajemen Perbankan, Edisi Revisi.Jakarta: PT.Raja Pers.

Kotler,Philip 2005. Manajemen Pemasaran. Jakarta: PT.Indeks Kelompok Gramedia.

Kotler,Philip dan Kevin Lane Keller. 2009 Manajemen Pemasaran. Jakarta: Erlangga.

Lupiyoadi, Rambat.2001. Manajemen Pemasaran Jasa. Jakarta : Salemba Empat.

Sugiyono.2001.Metodologi Penelitian Pendidikan. Bandung:Alfabeta

Umar,Husein.2011.Metode Penelitian Untuk Skripsi dan Tesis Bisnis, Edisi Kedua. Jakarta: PT. Raja Grafindo Persada.

www.bi.go.id

$\underline{\text { www.e-journal.unsrat.ac.id }}$

www.ojk.go.id

www.bankjateng.co.id

Yuliastanti, Arumsari 201. Analisis Pengaruh Marketing Mix Terhadap Pengambilan Keputusan Nasabah Menabung Pada Bank Jateng Cabang Koordinator Semarang. Tugas Akhir. Semarang : Politeknik Negeri Semarang. 